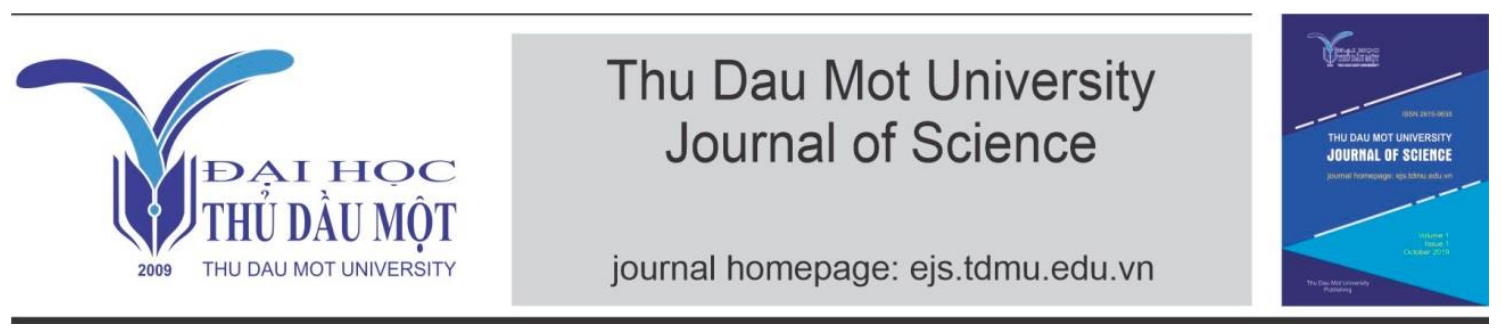

\title{
Assessment of the current status of waste sludge treatment of the industrial parks in Binh Duong Province
}

by Truong Quoc Minh, Nguyen Hien Than (Thu Dau Mot University, Vietnam)

Article Info: Received 10 Oct 2020, Accepted 25 Nov 2020, Available online 15 Dec, 2020

Corresponding author: minhtq@tdmu.edu.vn

https://doi.org/10.37550/tdmu.EJS/2020.04.087

\begin{abstract}
Study on sampling sludge from 04 industrial parks in Binh Duong province such as My Phuoc, Dong An, Viet Huong 1, Song Than 2 to analyze the pollution criteria to assess the pollution possibility of industrial waste sludge. The research results show that: at present, the total volume of sludge generated today in the industrial park fluctuates about 4,450 - 6,255 kg/day, equivalent to dry sludge volume is $1,035.725$ - 1,532.11 $\mathrm{kg} /$ day. The estimated volume of dry sludge generated from industrial parks in the future from 2019 to 2020 ranges from 30,023 to 31,396 kg/day. Most sludge from 04 wastewater treatment plants hadn't heavy metals $(\mathrm{Hg}, \mathrm{Pb}, \mathrm{Cu}, \mathrm{Ni}, \mathrm{Cr}, \mathrm{Zn}, \mathrm{Cd})$, especially Dong An Industrial park Treatment plant had Zn, value 49.7 - $49.9 \mathrm{mg} / \mathrm{l}$. The sludge from the wastewater treatment plants of 04 industrial parks had amount of helminth eggs that exceeds the USEPA's regulations on pathogens (type A sludge).
\end{abstract}

Key words: industrial park, sludge, treatment plant

\section{Introduction}

Currently, Binh Duong province has 48 industrial parks and industrial clusters, of which 29 are in operation (Binh Duong Provincial Statistics Office, 2017). Parallel to the establishment of an industrial park, Binh Duong province is facing a huge problem, which is the treatment of sludge generated from the industrial wastewater treatment 
plant. Waste sludge from wastewater treatment plants is a mixture of water and sediment that contains a lot of biodegradable organic matter, easily rot and contains bacteria that can be harmful to the environment (Ministry of Health, 2011).

In order to contribute to the implementation of environmental protection stemming from the waste disposal of industrial parks in Binh Duong province, the author conducts a study "Assessment of the current status of waste sludge treatment of the industrial parks in Binh Duong Province". The results of this study will provide quantitative information on pollution levels, causes and effects of sludge from industrial wastewater treatment plants. From there, set out pollution mitigation measures and sludge management plan.

\section{Materials and methods}

\section{Materials}

Data were obtained from sludge in 4 industrial parks in Binh Duong, including: My Phuoc, Dong An, Viet Huong 1, Song Than 2.

\section{Methods}

Field method: Conduct field surveys at all wastewater treatment plants of industrial parks in Binh Duong province, from which to study the current situation of generation, treatment, disposal and calculation of sludge volume of the industrial parks.

Method of investigation survey: 1) Number of centralized wastewater treatment plants of industrial parks in Binh Duong province; 2) Scale: wastewater flow ( $\mathrm{m}^{3} /$ day), volume of sludge (kg/year); 3) Current condition of sludge treatment and disposal.; 4) Number of concentrated wastewater treatment plants planned to be built in the future.

Sampling method, analyzing and experimenting pollution criteria: The analyzed sludge samples include: TS, TVS; heavy metals: $\mathrm{Cd}, \mathrm{Cr}, \mathrm{Cu}, \mathrm{Pb}, \mathrm{Hg}, \mathrm{Ni}, \mathrm{Zn}$ and analyzed by the method in Table 1 as follows:

TABLE 1. Analysis method of sludge pollution criteria

\begin{tabular}{ccl}
\hline No. & Parameter & \multicolumn{1}{c}{ Analytical method } \\
\hline 1 & TS, TVS, humidity & $\begin{array}{l}\text { Part 2540G.Standard Methods for the Examination of Water and } \\
\text { Wastewater (APHA, 1999) }\end{array}$ \\
2 & $\mathrm{Cd}, \mathrm{Cr}, \mathrm{Cu}, \mathrm{Pb}, \mathrm{Hg}, \mathrm{Ni}, \mathrm{Zn}$ & $\begin{array}{l}\text { Test Methods for Evaluating Solid Waste (USEPA, 2007): 1311 } \\
\text { và 3050 B }\end{array}$ \\
3 & Fecal Coliform & $\begin{array}{l}\text { Part 9221E or Part 9222D, Standard Methods for the Examination } \\
\text { of Water and Wastewater (APHA, 1999) }\end{array}$ \\
4 & Number of helminth eggs & $\begin{array}{l}\text { Environmental Regulations and Technology: Control of } \\
\text { Pathogens and Vectors in Sewage Sludge (USEPA, 2003) }\end{array}$ \\
& &
\end{tabular}


The method of evaluating the quality of sludge (Nemerrow pollution index):

$$
\mathrm{I}=\sqrt{\frac{\operatorname{MaxI}_{1}^{2}+\mathrm{AvgI}_{1}^{2}}{2}}
$$

In which: $\mathbf{I}_{\mathbf{i}}^{\mathbf{2}}$ : is the pollution index related to the observed concentration $\mathrm{C}_{\mathrm{i}}$ of pollutant $\mathrm{i}$ corresponding to the desired concentration $S_{i}$ (standard). $I_{i}=C_{i} / S_{i}$; Maxi $I_{i}$ is the maximum value of all $\mathrm{I}_{\mathrm{i}}$ directives; $\operatorname{Avg} \mathrm{I}_{\mathrm{i}}$ is the average value of all $\mathrm{I}_{\mathrm{i}}$ directives.

TABLE 2. Classification table of pollution levels (HaoYulin \& GeZhenchang, 1989)

\begin{tabular}{ccl}
\hline Classification & I & \multicolumn{1}{c}{ Pollution level } \\
\hline I & $<1$ & Clean water \\
II & {$[1,2)$} & mild pollution \\
III & {$[2,3)$} & polluted \\
IV & {$[3,5)$} & heavy pollution \\
V & $\geq 5$ & severe pollution \\
\hline
\end{tabular}

\section{Results}

3.1. The results of analysis of the environmental indicators of sludge from 4 centralized wastewater treatment plants

\section{My Phuoc Industrial park}

$T A B L E$ 3. Analysis results of heavy metals in sludge from My Phuoc Industrial Park Wastewater Treatment Plant

\begin{tabular}{lcccc}
\hline No & Heavy metal & \multicolumn{3}{c}{ Unit } \\
\cline { 3 - 5 } & & $\mathbf{M g} / \mathbf{k g}$ & $\mathbf{M g} / \mathbf{k g}$ & $\mathbf{M g} / \mathbf{l}$ \\
\cline { 3 - 5 } & & State $\mathbf{3}$ & State 2 \\
\hline 1 & $\mathrm{Hg}$ & Not detected & Not detected & Not detected \\
2 & $\mathrm{~Pb}$ & 17 & 11 & Not detected \\
3 & $\mathrm{Cu}$ & 22 & 28.6 & Not detected \\
4 & $\mathrm{Ni}$ & 2.7 & 7.4 & Not detected \\
5 & $\mathrm{Cr}$ & 397 & 141 & Not detected \\
6 & $\mathrm{Zn}$ & 113 & Not detected \\
7 & $\mathrm{Cd}$ & Not detected & Not detected & Not detected \\
\hline
\end{tabular}


Truong Quoc Minh, Nguyen Hien Than - Volume 2 - Issue 4-2020, p.435-441.

$T A B L E$ 4. The results of microbiological analysis in the sludge from My Phuoc Industrial Park Wastewater Treatment Plant

\begin{tabular}{clcc}
\hline No & \multicolumn{1}{c}{ Parameter } & \multicolumn{2}{c}{ Unit } \\
\cline { 3 - 4 } & & Egg/g (State 1) & Egg/g (State 2) \\
\hline 1 & Necator Americanus Ancylostoma sp & 189 & 0 \\
2 & Ascaris lumbricoides & 47 & 29 \\
3 & Trichostrongylus sp. & 0 & 29 \\
\hline
\end{tabular}

\section{Dong An Industrial park}

$T A B L E$ 5. Analysis results of heavy metals in sludge from Dong An Industrial Park Wastewater Treatment Plant

\begin{tabular}{ccccc}
\hline No & Heavy metal & \multicolumn{3}{c}{ Unit } \\
\cline { 3 - 5 } & & $\mathbf{M g} / \mathbf{k g}$ & $\mathbf{M g} / \mathbf{k g}$ & $\mathbf{M g} / \mathbf{l}$ \\
\cline { 3 - 5 } & & State $\mathbf{1}$ & \multicolumn{2}{c}{ State 2 } \\
\hline 1 & $\mathrm{Hg}$ & Not detected & $16-18$ & Notected \\
2 & $\mathrm{~Pb}$ & 3.4 & $744-756$ & Not detected \\
3 & $\mathrm{Cu}$ & 698 & $91-94$ & Not detected \\
4 & $\mathrm{Ni}$ & 214 & $247-250$ & Not detected \\
5 & $\mathrm{Cr}$ & 2900 & 4100 & $49.7-49.9$ \\
6 & $\mathrm{Zn}$ & Not detected & Not detected & Not detected \\
7 & $\mathrm{Cd}$ & & &
\end{tabular}

$T A B L E$ 6. The results of microbiological analysis in the sludge from Dong An Industrial Park Wastewater Treatment Plant

\begin{tabular}{llcc}
\hline No & \multicolumn{1}{c}{ Parameter } & \multicolumn{2}{c}{ Unit } \\
\cline { 3 - 4 } & & Egg/g (State 1) & Egg/g (State 2) \\
\hline 1 & Sparganum sp. & 0 & 0 \\
2 & Opisthorchis sp / Clonorchis sp & 123 & 0 \\
3 & Ascaris lumbricoides & 368 & 0 \\
\hline
\end{tabular}

\section{Viet Huong 1 Industrial park}

$T A B L E$ 7. Analysis results of heavy metals in sludge from Viet Huong 1 Industrial Park Wastewater Treatment Plant

\begin{tabular}{ccccc}
\hline \multirow{2}{*}{ No } & Heavy metal & \multicolumn{3}{c}{ Unit } \\
\cline { 3 - 5 } & & $\mathbf{M g} / \mathbf{k g}$ & $\mathbf{M g} / \mathbf{k g}$ & $\mathbf{M g} / \mathbf{l}$ \\
\cline { 3 - 5 } & & State $\mathbf{1}$ & \multicolumn{3}{c}{ State 2 } \\
\hline 1 & $\mathrm{Hg}$ & Not detected & Not detected & Not detected \\
2 & $\mathrm{~Pb}$ & 2.3 & 3.5 & Not detected \\
3 & $\mathrm{Cu}$ & 11.8 & 10 & Not detected
\end{tabular}




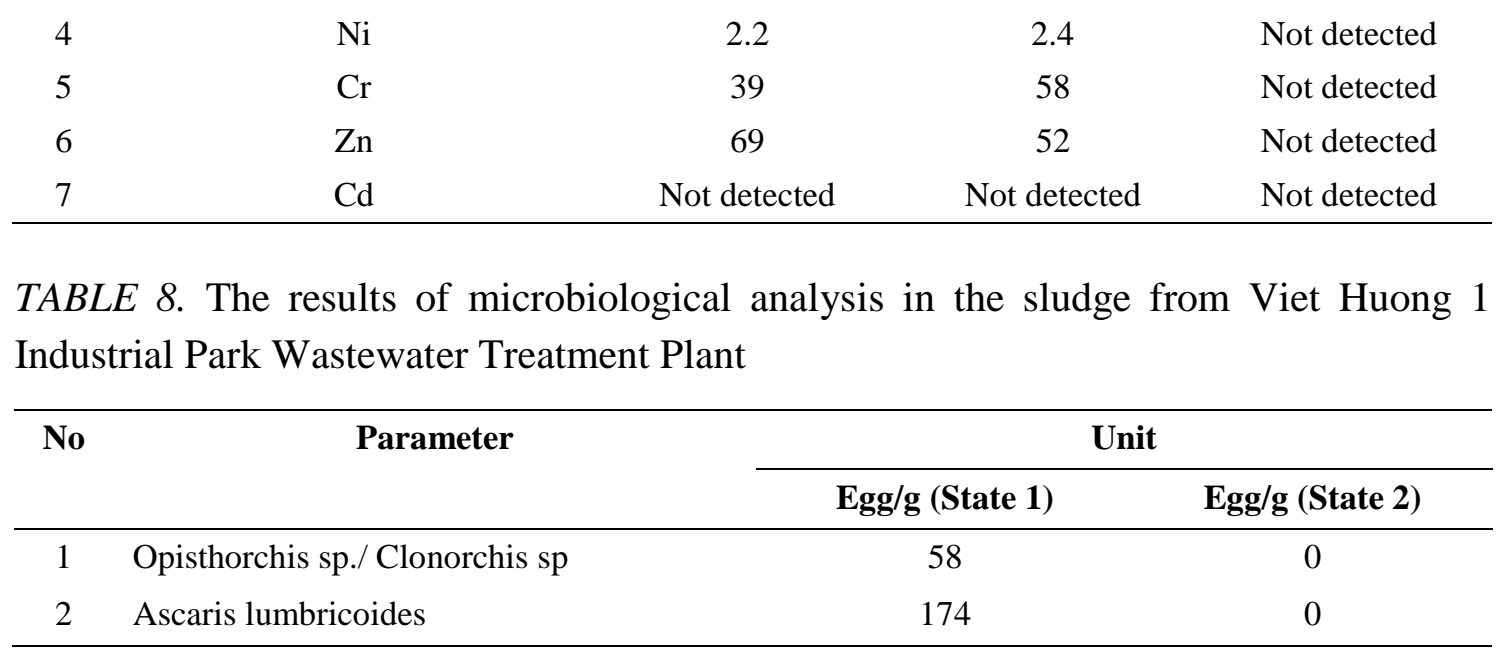

\section{Song Than 2 Industrial park}

TABLE 9. Analysis results of heavy metals in sludge from Song Than 2 Industrial Park Wastewater Treatment Plant

\begin{tabular}{ccccc}
\hline No & Heavy metal & \multicolumn{3}{c}{ Unit } \\
\cline { 3 - 5 } & & $\mathbf{M g} / \mathbf{k g}$ & $\mathbf{M g} / \mathbf{k g}$ & $\mathbf{M g} / \mathbf{l}$ \\
\cline { 3 - 5 } & & State $\mathbf{1}$ & State 2 \\
\hline 1 & $\mathrm{Hg}$ & Not detected & Not detected & Not detected \\
2 & $\mathrm{~Pb}$ & 2 & 2.5 & Not detected \\
3 & $\mathrm{Cu}$ & 33 & 18 & Not detected \\
4 & $\mathrm{Ni}$ & 4.1 & 3 & Not detected \\
5 & $\mathrm{Cr}$ & 45 & 54 & Not detected \\
6 & $\mathrm{Zn}$ & 34 & 25 & Not detected \\
7 & $\mathrm{Cd}$ & Not detected & Not detected & Not detected \\
\hline
\end{tabular}

TABLE 10. The results of microbiological analysis in the sludge from Song Than 2 Industrial Park Wastewater Treatment Plant

\begin{tabular}{llcc}
\hline No & \multicolumn{1}{c}{ Parameter } & \multicolumn{2}{c}{ Unit } \\
\cline { 3 - 4 } & & Egg/g (State 1) & Egg/g (State 2) \\
\hline 1 & Necator americanus/ancylostoma sp. & 0 & 7 \\
2 & Ascaris lumbricoides & 0 & 15 \\
\hline
\end{tabular}

\section{For heavy metals in sludge}

From the results table $3 ; 5 ; 7 ; 9$, we see that most of the sludge from 04 wastewater treatment plants do not detect heavy metals $(\mathrm{Hg}, \mathrm{Pb}, \mathrm{Cu}, \mathrm{Ni}, \mathrm{Cr}, \mathrm{Zn}, \mathrm{Cd})$, especially the wastewater treatment plant in Dong An industrial park had $\mathrm{Zn}$, value 49.7 - $49.9 \mathrm{mg} / \mathrm{l}$. Therefore, according to the EPA 1311 analysis method to determine the threshold of 
Truong Quoc Minh, Nguyen Hien Than - Volume 2 - Issue 4-2020, p.435-441.

hazardous waste, the sludge from the wastewater treatment plant of the four industrial zones above is not a hazardous waste, and can be managed as a normal waste.

\section{For the sludge microorganisms}

Total helminth eggs in the sludge of My Phuoc Industrial Park state 1 were 236 eggs/g, 59 times higher than the standard, state 2 were 58 eggs/g, 14.5 times higher than the USEPA's regulations on pathogens (type A ); the total eggs of helminths in the sludge of Dong An industrial park state 1 were $491 \mathrm{eggs} / \mathrm{g}$, exceeding the standard 122.75 times; the total eggs of helminths in the sludge of Viet Huong industrial park 1 state 1 were 232 eggs/g, 58 times higher than the standard; The total eggs of helminths in the sludge of Song Than 2 Industrial Park were $22 \mathrm{eggs} / \mathrm{g}$, exceeding the standard 5.5 times.

\subsection{Volume of sludge for industrial wastewater treatment}

The total volume of sludge generated today in the above 29 industrial parks ranges from $4,450-6,255 \mathrm{~kg} /$ day. According to the results of moisture analysis of 04 industrial parks selected for study samples, the average humidity is $81.75 \%$, so the amount of dry sludge ranges from $1,035.725$ to $1,532.11 \mathrm{~kg} /$ day. From there we can calculate the coefficient of dry sludge generation in Binh Duong province: $50 \mathrm{~kg} / 1,000 \mathrm{~m}^{3}$ of wastewater.

\section{Discussion}

On the basis of research and evaluation of the possibility of sludge contamination from a number of concentrated wastewater treatment plants of industrial parks in Binh Duong province, based on the US sludge application standards in the United States and In Europe, the research results show that:

Currently, the total volume of sludge generated today in the industrial park fluctuates about 4,450 - 6,255 kg/day, equivalent to dry sludge volume is 1,035.725 - 1,532.11 $\mathrm{kg} /$ day. The estimated volume of dry sludge generated from industrial zones in the future from 2019 to 2020 ranges from 30,023 to $31,396 \mathrm{~kg} / \mathrm{day}$.

For heavy metals in slude: According to the EPA 1311 analysis method to determine the threshold of hazardous waste, the sludge from the wastewater treatment plant of 04 industrial parks is not a hazardous waste, the sludge can be managed like normal waste.

For the sludge microorganisms: The sludge from the wastewater treatment plants of 04 industrial parks had amount of helminth eggs that exceeds the USEPA's regulations on pathogens (type A sludge), so sludge is not discharged into the soil, not used for the purpose of soil improvement and tree fertilization, appropriate management measures must be taken to avoid indiscriminate disposal. 


\section{References}

Ba Le Huy (1998). Ecological soil environment. Agricultural Publishing House.

Binh Duong Provincial Statistics Office (2017). Binh Duong Statistical Yearbook 2016. Young Publishing House.

Center for Research and Development for Energy Saving Ho Chi Minh City (2001). Lessons from the promulgation of Black Books and Green Books. Department of Science and Technology of Ho Chi Minh City.

Dang Pham Ngoc (2003). Air environment. Scientific and Technical Publishing House.

Dang Pham Ngoc (2000). Environmental management in urban and industrial park. Hanoi Construction Publishing House.

EPA (2011). Exposure factors handbook. United States Environmental Protection Agency.

HaoYulin \& GeZhenchang (1989). Water quality evaluation for rivers of Xinjiang in China. Paper presented at the Regional Characterization of Water Quality, China.

Ho Chi Minh City Institute of Environment and Resources (1997). Report on Research on wastewater and emission treatment technologies for some key industrial establishments in Ho Chi Minh City.Institute of Environmental Science and Technology (2005). Production documentation cleaner. Hanoi University of Technology.

Lan Dang Mong (2001). Environmental management tools. Hanoi Scientific and Technical Publishing House.

Ministry of Health (2011). Health care strategy. MOH. 